\title{
Early Printed Narrative Literature in Western Europe, éds. B. BESAMUSCA, E. DE BRUIJN \& F. WILLAERT
}

\author{
Maria Colombo Timelli
}

\section{(2) OpenEdition}

\section{Journals}

\section{Édition électronique}

URL : https://journals.openedition.org/studifrancesi/43559

DOI : $10.4000 /$ studifrancesi.43559

ISSN : 2427-5856

Éditeur

Rosenberg \& Sellier

\section{Édition imprimée}

Date de publication : 1 juin 2021

Pagination : 196-197

ISSN : 0039-2944

\section{Référence électronique}

Maria Colombo Timelli, «Early Printed Narrative Literature in Western Europe, éds. B. BESAMUSCA, E. DE BRUIJN \& F. WILLAERT », Studi Francesi [En ligne], 193 (LXV | I) | 2021, mis en ligne le 01 juillet 2021,

consulté le 15 octobre 2022. URL : http://journals.openedition.org/studifrancesi/43559; DOI : https:// doi.org/10.4000/studifrancesi.43559

Ce document a été généré automatiquement le 15 octobre 2022.

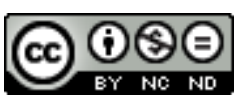

Creative Commons - Attribution - Pas d'Utilisation Commerciale - Pas de Modification 4.0 International - CC BY-NC-ND 4.0

https://creativecommons.org/licenses/by-nc-nd/4.0/ 


\title{
Early Printed Narrative Literature in Western Europe, éds. B. BESAMUSCA, E. DE BRUIJN \& F. WILLAERT
}

\author{
Maria Colombo Timelli
}

\section{RÉFÉRENCE}

Early Printed Narrative Literature in Western Europe, éds. B. BESAMUSCA, E. DE BRUIJN \& F. WILLAERT, Berlin, De Gruyter, 2019 (Open Access)

Comme le soulignent les trois éditeurs dans les pages préliminaires, «the aim of this book is to consider to what extent the shift from hand-written to printed books left its mark on narrative literature in a number of vernacular languages» (p. 2): c'est en effet une question qui occupe la critique depuis quelques années et qui encourage, fort heureusement, le dépassement de plusieurs frontières épistémologiques et disciplinaires, entre Moyen Âge et Renaissance, entre livre manuscrit et livre imprimé, entre moyen français et français «préclassique» pour nous en tenir à notre domaine. L'intérêt de ce volume est de franchir aussi la frontière entre langues, en prenant en compte la production en anglais, allemand, néerlandais, espagnol, et français bien entendu. Nous nous limiterons ici aux trois contributions susceptibles d'intéresser de plus près nos lecteurs, en les renvoyant tant à la Table qu'à l'ensemble des articles, tous disponibles en Open Access. 